\title{
Kariyer Kaygısının Aile Kurumuna ve Evlilik Kararına Etkisi
}

\author{
DOI: 10.26466/opus. 920663
}

\author{
* \\ Mukadder Özkan Bardakc1* \\ * Araş. Gör., Selçuk Üniversitesi, Beyşehir Ali Akkanat UBYO, Konya/Türkiye \\ E-Posta: mukadder.bardakci@selcuk.edu.tr \\ ORCID: $\underline{0000-0001-6827-9309}$
}

\begin{abstract}
Öz
Bu çalışmada kariyer kaygısının aile kurumuna ve evlilik kararına etkisi araştırılmıştır. Üniversite öğrencilerini kapsayan bu çalışmaya katılım să̆layan toplam öğrenci sayısı 187 dir. Örneklem grubu Beyşehir ilçesinde yer alan İşletme Fakültesi (651 öğrenci), Turizm Fakültesi (169 öğrenci), Meslek Yüksekokulu (1790), Uygulamalı Bilimler Yüksekokulu (321) öğrencileri arasından seçilmiştir. Bu araştırmada basit rastlantısal örneklem yolu kullanılmıştır. Öğrencilere iletişim araçları vasıtası ile ulaşılmaya çalışılması, kolay ulaşılabilecek verilerin zor elde edilmesine yol açmıştır. Araştırmada verileri elde etmek amacıyla çalışma grubunun kariyer kaygısı ile evliliğe ve aile kurumuna bakışlarını belirleyebilme adına demografik sorularla birlikte 90 soruluk anket uygulaması yapılmıştır. Anket çalışmasında yöntem olarak nicel araştırma ve soru cetveli kullanılmış olup veriler SPSS 20 paket programı ile analiz edilmiştir. Çalışmada frekans yüzde dağılımı verilmiştir. Çalışmaya katılım sağlayan üniversite öğrencilerinin aile kurarken eşlerinin kariyer ve iş sahibi olmalarina önem vermektedirler. Diğer yandan aşk, karşılıklı sevgi, mutlu ve huzurlu olmaya önem verdikleri görülmüş̧ür. Çalışmaya katılım să̆layan öğrenciler evlilikten korkmaktadır. Bunun sebebinin ise sorumluluk almak ve evlendikten sonra evlilik öncesi tanımış oldukları eşlerinin evlilikle birlikte değişeceğgi düşüncesi olarak ifade etmişlerdir.
\end{abstract}

Anahtar Kelimeler: Kariyer Kaygısı, Evlilik Kararı, Aile Kurumu. 


\title{
The Effect of Career Anxiety on Family Institution and Marriage Decision
}

\begin{abstract}
In this study, it is investigated the impact of career anxiety on family institution and marriage decision making. Including university students, 187 students took part in study. Sample group was picked from the students in Faculty of Management (651 students), Faculty of Tourism (169 students), Vocational School (1790 students) and School of Applied Sciences (321 students) in Beyşehir district. In this study the method of simple random sampling was used. Trying to communicate with students via media made it difficult to obtain data while it could be obtained easily. A questionnaire with 90 questions including demographic questions was applied in the study to obtain data for the purpose of determining point of views of study group to marriage and family institution with career anxiety. In questionnaire quantitative research and questions were used as methods, the data was analyzed SPSS 20 programme. In the study, there is frequency distribution. The students taking part in the study regard that their partners have a career or a job. On the other hand, they also care mutual love and being happy. The students fear from marriage. They expressed the reason for this as taking responsibility and the thought that the spouses they met before marriage will change with marriage.
\end{abstract}

Keywords: Career Anxiety, Marriage Decision, Family Institution. 


\section{Giriş}

İnsanın dünyaya geldiği en küçük yapı ailedir. Toplumun temelini oluşturan en önemli kurumlardan biri şüphesiz ailedir. İnsan gündelik tüm bilgi ve becerilerini ailede öğrenir. Aile eğitim alınan ilk okuldur. Eğitim ve öğrenme süreci ailede başlayarak okul sıralarına taşınmaktadır. Tüm eğitim hayatı düşünüldüğünde insan ortalama on altı yılını eğitim için harcamaktadır. Eğitim hayatı sonunda ise bir meslek sahibi olmak hayata tutunmak hayalleri arasındadır. Bu süreçte insan bir yandan meslek sahibi olup kariyer planması yaparken diğer yandan ise evlilik çağına adım atmaktadır. Kariyere sahip olmak, kariyerli bir meslek yapmak ya da hayalini kurduğu işe ulaşmak insanın evlilik sürecini ve evliliğe bakışını da etkilediği düşünülmektedir. Yapılan bu çalışmada kariyer kaygısının evlilik kararını ve aile kurumunu ne şekilde etkilediği araştırılmıştır.

İnsanoğlu hayata gözünü açtı̆̆ı andan itibaren toplumun içinde var olmuştur. Özel durum veya şartlar dışında insan yaşamını küçük veya büyük grupların içinde sürdürmüştür (Balaman, 1984). Toplumsal varlık olan insan bu grupların içinde yaşadığından hayatında önemli kararlar verirken içinde yaşadığı gruplardan çocukluğundan itibaren etkilenmiştir.

Kariyer gelişimi çocukluk dönemi ile hayatımıza girmiştir. Bu gelişim, özellikle gençlik ve üniversite yıllarında hayata geçişte önemlidir. Bu dönemde kariyer ile ilgili kararlar alırken ailenin etkisi, ekonomik koşullar, gelecek yaşam ile ilgili beklentiler bireyleri etkileyerek kaygı yaşamalarına sebep olmaktadır. Özellikle 15-24 yaş aralığında lise ve üniversite yıllarını da içine alan dönem yoğun bir şekilde kariyer planının yapıldığı dönemdir (Okutan ve Akbaş,2019). Öğrenim süresince bir mücadele içerisinde olan genç genellikle üniversiteyi kazanması ile birlikte kaygısının sonlanacağını düşünse de üniversite döneminin sonlarına doğru kariyer yapma, bir işe sahip olma ve gelecekle ilgili beklentilerinde stres yaşamaya başlamaktadır (Çakmak ve Hevedanlı, 2005). Aslında bu stres durumu insanlara ve onların kariyer anlayışına göre değişmektedir.

Kariyer, insanların ömürlerinin sonuna kadar yaptığı tüm işlerdir. Kaygı ise özellikle insanın önündeki zaman diliminde duyduğu stres ve korkularıdır. Bu bağlamda kariyer kaygısı ise, insanların kariyerlerindeki 
belirsizlikten ortaya çıkan stres durumudur (Göncü -Akbaş,2019). İnsanlar hayatlarının büyük bir kısmında çalışmak zorunda kaldıklarından özellikle 2000 sonrası iş hayatına atılan kesim için son dönemde kariyer planı yapmak önemli bir nokta haline gelmiştir. Kariyerin ilk basamağı genellikle orta öğretim olarak görülse de son dönemde özellikle kariyer planlamasının anaokulları ve kreşlerden başlayarak ömür boyu sürmektedir. Aileler artık sadece lise, üniversite ya da iş hayatına girişte değil ilk eğitime başladıkları günlerden itibaren çocuklarına kariyer baskısı oluşturabilmektedir. Ancak en yoğun olarak meslek seçimi ve iş hayatına geçişte aile baskısının ve kariyer kaygısının arttığı söylenebilir.

Üniversite öğrencilerinin birçoğu kariyer planlamasından dolayı zorluklar çekmekte ve zorluğun sonucu olarak da yüksek ölçüde ruhsal sıkıntılar yaşamaktadır (Fouad vd., 2006). Özellikle üniversite yaşamı bitince işsiz kalma korkusu, toplumun ve sosyal çevrenin birey üzerindeki baskısı bu durumu daha da ağır hale getirmektedir. İş kaygısı çeken bireyin bu dönemde üniversite eğitiminin bitmesi ile yuva kurması beklenmektedir. Her ne kadar modernleşme ve bireyselleşme ile beraber bu beklentilerin etkisi azalmış olsa da hala günümüzde bu baskı devam etmektedir.

Bu zorlu süreçte bireyler hem kariyer sıkıntısı yaşarken hem de toplumun beklentilerinden dolayı artık bir yuva kurması istenmektedir. Ancak modernleşmeyle beraber toplumlarda yaşanan değişim ile eski aile bağlarının yerini bireyselleşmeye bıraktığı ileri sürülmektedir. Bunu da aile yaşamı, evlilikler ve insanların bunlara yönelik tutumları üzerinden fark edilebileceği iddia edilmektedir (Eroğlu,2017). Bu baskı bireylerde ilk olarak bir eş arama ve yuva kurmaya itmektedir. Bu amaçla bireyler ilk olarak eş adayını belirledikten sonra evlilik yolunu tercih etmektedir. Bu sebeple insanları bir araya getiren evlilik Tandoğan (1965)' a göre, bireylerin aile çatısında birleşmesi, yeni hayatlarına yönelik bütün hedeflerinde ve mücadelelerinde, hüzün ve mutluluklarında birlikte olmasıdır. (Tandoğan, 1965, s.1). Atasoy (1994, s.11) ise evliliği iki bireyin ben yerine biz düşüncesinin oluştuğu, birbirlerinin maneviyatını besleyen ve ortak değerlerde birleşen iki kalp şeklinde tanımlamaktadır. Evlilik insanlara ruhsal ve sosyal yönden yarar sağlayan, güzel bir hayat sunan müessesedir. İnsanların evlilik hayatındaki durumunun tüm hayatına da paralel oranda etki ettiği söylenebilir. Bu sebeple insanlar evliliklerinde 
memnun oldukları taktirde hayatlarından da memnun olacağ düşünülmektedir. (Çağ ve Yıldırım, 2013, s.14).

İnsanlar tüm bu gelişmeler 1şı̆̆ında evlenir ve aile kurar. Her ne kadar aile ve evlilik kavramları aynı anlamlara geliyor gibi görünse de nüanslar vardır. Yörükoğlu'nun da belirttiği gibi aile; insanların manevi ve cinsel ihtiyaçlarını karşıladığı, çocuklarının sorumluluklarının paylaşıldığı ve geleceğe yönelik beklentilerin karşılandığı kurumdur (Yörükoğlu, 2000, s.125). En sıcak birincil ilişki alanıdır (Sarı, 2013, s.17). Sosyal bilimcilerin de üzerine çalıştı̆̆ kavramlardan olan aile, insanların ilk dünyaya geldiği zamandan başlayarak birlikte olduğu, bakım noktasında yardım edilen kurumdur (Akkaya,2018, s.4). Ailenin her ne kadar bakım ve manevi ihtiyaçları giderme gibi fonksiyonları olsa da insanların hayatındaki anlamını açıklamak için yetersizdir. Aile, insanlara sosyalleşme ortamını ilk olarak sağlayan, bireyleri arasında güvene dayalı, candan bağ kuran toplumun en küçük kurumlarındandır (Ozankaya,1996). Geçmişten bu güne aile sosyal bilimler için merak konusu olmuştur (Can, 2013, s.65). Aile toplumsalın içinde önemli bir yere sahiptir (Nacak ve Karaarslan, 2013, s.121).

Alanyazın incelendiğinde evlilik ve aile ile ilgili tanımlar her ne kadar ideal olanı anlatıyor olsa da özellikle kariyer planı yapan bireylerin üniversite sonrası evlilik yapacak, aile kuracak, ev geçindirebilecek ekonomik durumlarının olmamasından dolayı ilk talep edecekleri şey çalışma ve iştir. Yörükoğlu'nun da belirttiği bu dönemdeki bireyler becerilerini ve ilgilerini saptamaya, nerede çalışacağını belirlemeye uğraşmaktadır. Ancak iş arama konusunda tecrübesiz olmaları ve mesleki becerilerinin olmamasından dolayı stres yaşamakta ve yardıma ihtiyaç duymaktadırlar (Yörükoğlu, 2004, s.41- 45).

Kısaca 21. yy dünyasında bireylerin iş kaygısının artması, kendi lükslerinden feragat etmek istememeleri, bir aile oluşturmak için öncesinde üstesinden gelmesi gereken ekonomik gerekliliklerden dolayı insanların geçmişe göre evlilik kararını daha zor verdiği gözlemlenmektedir. Tüm bu gelişmeler ışığında bu araştırmada, günümüz gençliğinin kariyer kaygısı ve evlilik kararını etkileyen durumlar incelenecektir. 


\section{Yöntem}

Çalışmada Selçuk Üniversitesi Beyşehir Ali Akkanat Kampüsünde eğitim gören tüm üniversiteli gençlere ulaşılması planlanmış olup, çalışma sürecinin Covid 19 pandemisine denk gelmesi katılımclara ulaşmada zorluk çekilmesi ile sınırlandırılmıştır. Çalışmaya katılım sağlayan toplam öğrenci sayısı 187 dir. Örneklem grubu Beyşehir ilçesinde yer alan İşletme Fakültesi (651 öğrenci), Turizm Fakültesi (169 öğrenci), Meslek Yüksekokulu (1790), Uygulamalı Bilimler Yüksekokulu (321) öğrencileri arasından seçilmiştir. Bu araştırmada basit rastlantısal örneklem yolu kullanılmıştır. Öğrencilere iletişim araçları vasıtası ile ulaşılmaya çalışıması, kolay ulaşılabilecek verilerin zor elde edilmesine yol açmıştır. Araştırmada verileri elde etmek amacıyla çalı̧̧ma grubunun kariyer kaygısı ile evliliğe ve aile kurumuna bakışlarını belirleyebilme adına demografik sorularla birlikte 90 soruluk anket uygulaması yapılmıştır. Anket çalışmasında yöntem olarak nicel araştırma ve soru cetveli kullanılmış olup veriler SPSS 20 paket programı ile analiz edilmiştir. Çalışmada frekans yüzde dağılımı verilmiştir.

\section{Bulgular}

Tablo 1. Katılımcıların Sosyodemografik Özellikleri

\begin{tabular}{lll}
\hline Cinsiyet & Sayı (n) & Yüzde (\%) \\
Kadın & 134 & 71,7 \\
Erkek & 53 & 28,3 \\
\hline Doğum Yılı & Sayı (n) & Yüzde (\%) \\
1995 ve öncesi & 8 & 4,3 \\
$1996-2000$ arası & 117 & 62,6 \\
2001 ve üstü & 62 & 33,2 \\
\hline Medeni Durum & Sayı (n) & Yüzde (\%) \\
Sözlü & 2 & 1,1 \\
Nişanlı & 2 & 1,1 \\
Bekar & 179 & 95,7 \\
Evli & 3 & 1,6 \\
Dul & 1 &, 5 \\
\hline Bölüm & Sayı (n) & Yüzde (\%) \\
Sosyal Hizmet & 82 & 43,9 \\
AYAY & 20 & 10,7 \\
Yönetim Bişişimi & 20 & 10,7 \\
Aş̧ıllık & 18 & 9,6 \\
Ul. Ar. Ticaret & $\mathbf{1 3}$ & 7,0 \\
Bankacllı & 17 & 9,1 \\
Diğer & 17 & 9,1 \\
\hline Mezun Lise & & \\
Düz Lise & 14 & 7,5 \\
Meslek Lisesi & 52 & 28,3
\end{tabular}




\begin{tabular}{|c|c|c|}
\hline İmam Hatip Lisesi & 24 & 12,8 \\
\hline Anadolu Lisesi & 90 & 48,1 \\
\hline Diğer & 6 & 3,2 \\
\hline \multicolumn{3}{|l|}{ Aile Gelir } \\
\hline $0-1500$ & 17 & 9,1 \\
\hline $1500-3000$ & 77 & 41,2 \\
\hline $3000-4500$ & 43 & 23,0 \\
\hline $4500-6000$ & 25 & 13,4 \\
\hline $6000-7500$ & 13 & 7,0 \\
\hline 7500 üstü & 12 & 6,4 \\
\hline \multicolumn{3}{|l|}{ Anne Eğitim } \\
\hline Okur Yazar Değil & 20 & 10,7 \\
\hline İlkokul Mezunu & 103 & 55,1 \\
\hline Ortaokul Mezunu & 37 & 19,8 \\
\hline Lise Mezunu & 18 & 9,6 \\
\hline Lisans ve Lisansüstü & 9 & 4,8 \\
\hline \multicolumn{3}{|l|}{ Baba Eğitim } \\
\hline Okur Yazar Değil & 4 & 2,1 \\
\hline İlkokul Mezunu & 70 & 37,4 \\
\hline Ortaokul Mezunu & 38 & 20,3 \\
\hline Lise Mezunu & 56 & 29,9 \\
\hline Lisans ve Lisansüstü & 19 & 10,2 \\
\hline \multicolumn{3}{|l|}{ Yaşanılan Şehir } \\
\hline Köy & 28 & 15,0 \\
\hline Kasaba & 8 & 4,3 \\
\hline İlçe & 44 & 23,5 \\
\hline İl & 48 & 25,7 \\
\hline Büyükşehir & 59 & 31,6 \\
\hline \multicolumn{3}{|l|}{ Aile Türü } \\
\hline Çekirdek & 140 & 74,9 \\
\hline Geniş & 35 & 18,7 \\
\hline Parçalanmış & 12 & 6,4 \\
\hline \multicolumn{3}{|c|}{ Ebeveynlik Evlilik Durumu } \\
\hline Resmi Nikahla Evli & 170 & 90,9 \\
\hline Boşanmış & 7 & 3,7 \\
\hline Anne veya Baba Vefat & 10 & 5,3 \\
\hline \multicolumn{3}{|l|}{ Flört Durumu } \\
\hline Evet & 70 & 37,4 \\
\hline Hayır & 117 & 62,6 \\
\hline
\end{tabular}

Katılımcıların \%71,7'si erkekken \%28,3'ü kadındır. Katılımcıların \%4,3'ü 1995 ve öncesinde, \%62,6'sı 1996-2000 yılları arasında ve \%33,2'si 2001 ve üzerinde dünyaya gelmiştir. Katılımcıların \%95,7'si bekar ve \%1,6's1 evli olup \%43,9' u Sosyal Hizmet Bölümünü okumaktadır. Araştırmaya katkı sağlayan bireylerin \%41,2'si 1500-3000 TL arasında ve $\% 6,4^{\prime}$ ü 7500 üzeri aile gelirine sahiptir. Eğitim düzeylerine bakınca annelerin $\% 55,1$ i ilkokul mezunu iken babaların \%50,2'si ortaokul ve lise mezuniyetine sahiptir. Lisans ve lisansüstü eğitime sahip annelerin oranı $\% 4,8$ iken lisans ve lisansüstü eğitime sahip babaların oranı 10,4'tür. Kat1lımcıların \%57,3'ü ömrünün büyük kısmını il ve büyükşehirlerde geçirmiştir. Anne-baba evlilik durumuna bakıldığında \%90,1 i resmi nikahla evlidir. Katılımcıların \%62,6'sının de flörtü bulunmamaktadır. 
Tablo 2. Eş seçimi noktasında size en uygun durum hangisidir?

\begin{tabular}{lll}
\hline & Sayı(n) & Yüzde (\%) \\
\hline Kararı Ben Veririm Kimseye Danışmam & 10 & 5,3 \\
Kararı Ben Veririm Sonra Ailemin Onayını Alırım & 169 & 90,4 \\
Kararı Ailem Verir Sonra Benim Onayımı Alır & 8 & 4,3 \\
Total & 187 & 100,0 \\
\hline
\end{tabular}

Tablo 2 incelendiğinde araştırmaya katılan bireylerin eş seçiminde en uygun durum olarak \%90,4 (169)'u kararı kendisinin vereceğini sonrasında ailesinin onayını alacağını ifade ederken \%5,3 (10)'u kararı kendinin vereceğinin ve kimseye danışmayacağını ifade etmiştir. \%4,3 (8)'u ise kararı ailesinin vereceğinin sonrasında kendisinden onay alacağını belirtmiştir.

Tablo 3. Eş seçiminde kariyer sahibi olmak

\begin{tabular}{lll}
\hline & Sayı (n) & Yüzde (\%) \\
\hline Çok Önemli & 71 & 38,0 \\
Kısmen Önemli & 97 & 51,9 \\
Önemsiz & 19 & 10,1 \\
Total & 187 & 100,0 \\
\hline
\end{tabular}

Tablo 3 incelendiğinde araştırmaya katılan bireylerin eş seçiminde kariyere sahibi olmanın çok önemli olduğunu düşününler \%38(71)'ken kısmen önemli olduğunu ifade edenlerin oranı ise \%51,9 (97)'dir. Katılımc1ların çoğu eş seçiminde kariyer sahibi olmanın önemli olduğunu düşünmektedir. Önemsiz olduğunu düşünen kişilerin sayısı çok önemli ve kısmen önemli cevabını verenlere göre azdır. Bu oranlar da gençlerin eş seçerken kariyer sahibi olmasının önemli olduğunu göstermektedir.

Tablo 4. Hayatınızda biri varsa ilk kiminle paylaşırsınız?

\begin{tabular}{lll}
\hline & Sayı $\mathbf{( n )}$ & Yüzde (\%) \\
\hline Annem & 40 & 21,4 \\
Babam & 16 & 8,6 \\
Her İkiside & 119 & 63,6 \\
Arkadaşıma & 12 & 6,4 \\
Total & 187 & 100,0 \\
\hline
\end{tabular}

Tablo 4 incelendiğinde araştırmaya katılan bireylerin hayatlarında biri varsa ilk olarak hem annesi hem babası ile paylaşacaklarını belirtenlerin oranı oranı \%63,6 (119)'dur. İkinci en fazla yüzdeye sahip olan cevap ise anneleri $(\% 21,4)$ ile paylaşacakları cevabıdır. Çalışmaya katılan gençlerin 
hayatlarına birinin girmesi durumunda öncelikli paylaşım yapacağı kişilerin aile üyesi olduğu görülmektedir. Arkadaşlarından ziyade aile üyeleri ile paylaşımda bulunmayı tercih ettikleri görülmüştür. Oransal olarak baktığımızda arkadaşa danışma en son sırada yer almaktadır.

Tablo 5. Katılımcıların Eş Seçiminde Tercih Durumları

\begin{tabular}{lllllllll}
\hline \multirow{2}{*}{ Eş Seçiminde } & \multicolumn{2}{l}{ Çok Önemli } & \multicolumn{2}{l}{ Kısmen Önemli } & \multicolumn{2}{l}{ Önemsiz } & \multicolumn{2}{l}{ Toplam } \\
\cline { 2 - 9 } & Sayı & $\mathbf{\%}$ & Sayı & $\mathbf{\%}$ & Sayı & $\mathbf{\%}$ & Sayı & \% \\
\hline Aşk durumu & 153 & 81,8 & 31 & 16,6 & 3 & 1,6 & 187 & 100 \\
Kültürel durum & 134 & 71,7 & 50 & 26,7 & 3 & 1,6 & 187 & 100 \\
Hayata bakış durumu & 173 & 92,5 & 13 & 7,0 & 1 &, 5 & 187 & 100 \\
\hline
\end{tabular}

Tablo 5 incelendiğinde eş seçiminde katılımcılara tercihleri sorulmuştur. Özellikle tercih edecekleri kişiye âşık olmaları ve hayata bakışlarının büyük ölçüde önemli olduğu görülmüştür. Katılımcılardan hayata bak1şın çok önemli olduğunu belirtenlerin oranı \%92, 5 `ken âşık olmanın çok önemli olduğunu belirtenlerin oranı ise \%81, 8' dir. Aynı zamanda katılımcıların \%71, 7'si seçecekleri eşleriyle kültürel olarak uyum yaşamalarının önemli olduğunu da belirtmişlerdir. Çalışmaya katılım sağlayan gençler evlilik yapmak için evlenecekleri kişiye âşık olmayı, evleneceği kişiyle hayata bakışlarının aynı olmasını ve kültürel olarak uyum içinde olmayı önemli ölçüde tercih ettikleri görülmüştür.

Tablo 6. Eş seçiminde eğitim durumu

\begin{tabular}{lll}
\hline & Sayı (n) & Yüzde (\%) \\
\hline Erkek Daha Eğitimli Olmalı & 13 & 7,0 \\
İkisi de Aynı Düzeyde Olmalı & 111 & 59,4 \\
Fark Etmez & 63 & 33,7 \\
Total & 187 & 100,0 \\
\hline
\end{tabular}

Tablo 6 incelendiğinde araştırmaya katılan bireyler eşlerin eğitim düzeyi için \%59,4 (111)'ü eşlerin aynı eğitim seviyesinde olması gerektiğini ifade ederken fark etmez cevabını verenlerin oranı ise \%33,7 (63)'dir. Katılımcıların yarısından fazlası eşlerin eğitim düzeyinin aynı olması görüşündedir. Gençlerin eş tercihinde eğitim düzeylerine önem verdikleri söylenebilir. Aynı zamanda eğitim durumunun fark etmeyeceğini ifade edenlerin oranı da dikkat çekmektedir. Çalışmaya katılanlardan $63(\% 33,7)$ kişi eğitim durumunun fark etmeyeceği cevabını vermiştir. 
Tablo 7. Eş seçiminde ekonomik durum

\begin{tabular}{lll}
\hline & Sayı (n) & Yüzde (\%) \\
\hline Erkeğin Ekonomik Durumu Daha İyi Olmalı & 45 & 24,1 \\
Kadının Ekonomik Durumu Daha İyi Olmalı & 2 & 1,1 \\
Her İkisi de Aynı Düzeyde Olmalı & 64 & 34,2 \\
Fark Etmez & 76 & 40,6 \\
Total & 187 & 100,0 \\
\hline
\end{tabular}

Tablo 7 incelendiğinde araştırmaya katılan bireylere eş seçiminde ekonomik durum sorulmuştur. Katılımcıların \%40,6 (76)'sı fark etmez cevabını verirken. \%34,2 (64)'si ise her iki eşinde aynı düzeyde olması gerektiğini ifade etmiştir.

Tablo 8. Sanal ortamda bulduğun biri ile evlenme durumu

\begin{tabular}{lll}
\hline & Sayı $(\mathbf{n})$ & Yüzde (\%) \\
\hline Evet & 28 & 15,0 \\
Hayır & 74 & 39,6 \\
Kararsızım & 85 & 45,5 \\
Total & 187 & 100,0 \\
\hline
\end{tabular}

Tablo 8 incelendiğinde araştırmaya katılan bireylerin sanal ortamda tanıştığ 1 biriyle evlenme durumu sorulmuş ve \%45,5'i kararsız olduğunu söylemiştir. Sanal ortamda tanıştığı biriyle evlenmeyeceğini belirtenlerin oranı ise \% 39,6 'dır.

Tablo 9. Eş Tercihinde Yakın Çevrenin Görüşleri

\begin{tabular}{lllllllll}
\hline Eş Tercihinde & \multicolumn{2}{l}{ Çok Önemli } & \multicolumn{2}{l}{ K1smen Önemli } & \multicolumn{2}{l}{ Önemsiz } & \multicolumn{2}{l}{ Toplam } \\
\cline { 2 - 9 } & Say1 & $\mathbf{\%}$ & Say1 & \% & Say1 & \% & Say1 & \% \\
\hline Anne düşüncesi & 143 & 76,5 & 42 & 22,5 & 2 & 1,1 & 187 & 100 \\
Babanın düşüncesi & 130 & 69,5 & 44 & 23,5 & 13 & 7,0 & 187 & 100 \\
Arkadaşın düşüncesi & 34 & 18,2 & 96 & 51,3 & 57 & 30,5 & 187 & 100 \\
Akrabaların düşüncesi & 4 & 2,1 & 64 & 34,2 & 119 & 63,6 & 187 & 100 \\
\hline
\end{tabular}

Tablo 9 incelendiğinde katılımclar eş tercih ederken anne ve babanın düşüncesinin çok önemli olduğunu belirtmişlerdir. Oransal olarak baktığımızda da annenin düşüncesinin çok önemli olduğunu ifade edenlerin oranı $\% 76,5^{\prime}$ ken babanın düşüncesinin çok önemli olduğunu belirtenlerin oranı ise \%69,5 dir. Arkadaşların (\% 51,3) ve akrabaların (\%34,2) düşüncelerinin ise kısmen önemli olduğu görülmektedir. Arkadaşın eş tercihi hakkında ki görüşünün akrabaya nazaran daha önemli olduğunu belirtenlerin oranı daha yüksektir. Gençler eş seçiminde öncelikli olarak anne ve 
babanın fikirlerine önem verirken sonra arkadaş ve akrabaların görüşlerini önemsemektedir.

Tablo 10. Eş seçiminde dini inanç durumu

\begin{tabular}{lll}
\hline & Sayı $(\mathbf{n})$ & Yüzde (\%) \\
\hline Çok Önemli & 140 & 74,9 \\
Kismen Önemli & 33 & 17,6 \\
Önemsiz & 14 & 7,5 \\
Total & 187 & 100,0 \\
\hline
\end{tabular}

Tablo 10 incelendiğinde araştırmaya katılan bireylerin $\% 74,9^{\prime} \mathrm{u}$ eş seçiminde dini inanışların çok önemli olduğunu belirtirken $\% 7,5^{\prime}$ ine göre dini inancın önemsiz olduğunu belirtmiştir.

Tablo 11. Kadın için ideal evlilik yaşı

\begin{tabular}{lll}
\hline & Sayı $(\mathbf{n})$ & Yüzde $(\mathbf{\%})$ \\
\hline $18-20$ arası & 3 & 1,6 \\
$21-23$ arası & 33 & 17,6 \\
$24-26$ arası & 122 & 65,2 \\
$27-29$ arası & 28 & 15,0 \\
30 ve üstü & 1 &, 5 \\
Total & 187 & 100,0 \\
\hline
\end{tabular}

Tablo 11 incelendiğinde araştırmaya katılan bireylerin kadınlar için ideal evlilik yaşının \%65, (122)'inin 24-26 arası olduğunu belirtirken \%17, 6 (33)'sının ise 21-23 arası olarak ifade ettiği görülmüştür.

Tablo 12. Erkek için ideal evlilik yaşı

\begin{tabular}{lll}
\hline & Sayı $\mathbf{( n )}$ & Yüzde (\%) \\
\hline $18-20$ arası & 1 &, 5 \\
$21-23$ arası & 9 & 4,8 \\
$24-26$ arası & 88 & 47,1 \\
$27-29$ arası & 73 & 39,0 \\
30 ve üstü & 16 & 8,6 \\
Total & 187 & 100,0 \\
\hline
\end{tabular}

Tablo 12 incelendiğinde erkekler için ideal evlilik yaşının 24-26 olarak görenlerin sayısı 88' dir. Aynı zamanda araştırmaya katılan 73 kişi ise ideal evlilik yaşını 27-29 olarak görmektedir.

Tablo 13. Evlilik İçin Gerekli Olan Kriterler

\begin{tabular}{|c|c|c|c|c|c|c|c|c|}
\hline \multirow[t]{2}{*}{ Evlilik için } & \multicolumn{2}{|c|}{ Çok Önemli } & \multicolumn{2}{|c|}{ Kismen Önemli } & \multicolumn{2}{|c|}{ Önemsiz } & \multicolumn{2}{|c|}{ Toplam } \\
\hline & Sayı & $\%$ & Sayı & $\%$ & Sayı & $\%$ & Say1 & $\%$ \\
\hline Üniversite mezunu olmalı & 57 & 30,5 & 88 & 47,1 & 42 & 22,5 & 187 & 100 \\
\hline İşs sahibi olmalı & 169 & 90,4 & 16 & 8,6 & 2 & 1,1 & 187 & 100 \\
\hline Kariyer sahibi olmalı & 82 & 43,9 & 83 & 44,4 & 22 & 11,8 & 187 & 100 \\
\hline
\end{tabular}


Tablo 13 incelendiğinde evlilik için gerekli olan şartlara baktığımızda özellikle evlilik birliği gerçekleştirilirken iş sahibi olunmasının çok önemli olduğunu belirtenlerin oranı \%90,4 olduğu görülmektedir. Katılımcıların vermiş oldukları cevaplara baktığımızda üniversite mezunu olmasının kısmen önemli $(47,1)$ olduğunu düşünenlerin oranı çok önemli $(\% 30,5)$ ve önemsiz $(\% 22,5)$ diyenlere göre nispeten daha yüksektir. Evlenecekleri eşlerinin kariyer sahibi olmasının önem durumuna baktığımızda katılımcı sayısı olarak baktığımızda çok önemli olduğunu düşünenlerin sayısının 82 kısmen önemli olduğunu ifade edenlerin sayısı ise 83'tür. Çok önemli ve kısmen önemli olduğunu ifade edenlerin sayısı hemen hemen aynıdır. Katılımcıların cevaplarında en dikkat çeken evlilik için iş sahibi olunmasının gerekliliği fikrinin yüksek oranda ortak düşünce olmasıdır.

Tablo 14. Evlilik neslin devamı için

\begin{tabular}{lll}
\hline & Sayı (n) & Yüzde (\%) \\
\hline Çok Önemli & 80 & 42,8 \\
Kismen Önemli & 82 & 43,9 \\
Önemsiz & 25 & 13,3 \\
Total & 187 & 100,0 \\
\hline
\end{tabular}

Tablo 14 incelendiğinde araştırmaya katılanların \%42,8 (80)'i çok önemli olduğunu ifade ederken kısmen önemli olduğunu ifade edenlerin oranı ise $\% 43,9(82)^{\prime}$ dur.

Tablo 15. Evlilikte mutlu yuva için anlayış

\begin{tabular}{lll}
\hline & Sayı (n) & Yüzde (\%) \\
\hline Çok Önemli & 185 & 98,9 \\
Kismen Önemli & 2 & 1,1 \\
Total & 187 & 100,0 \\
\hline
\end{tabular}

Tablo 15 incelendiğinde araştırmaya katılan bireylerin evlilikte mutlu yuvanın olması için anlayışlı olunması gerektiğini belirtenler \%98,9 iken kısmen önemli olarak görenler \%1,1'dir. Önemsiz olarak gören hiçbir katılımcı çıkmamıştır.

Tablo 16. Evlilikte mutlu yuva için birbirine destek

\begin{tabular}{lll}
\hline & Sayı (n) & Yüzde (\%) \\
\hline Çok Önemli & 186 & 99,5 \\
Kismen Önemli & 1 &, 5 \\
Total & 187 & 100,0 \\
\hline
\end{tabular}


Tablo 16 incelendiğinde araştırmaya katılan bireylerin evlilikte mutlu yuvanın olması için birbirine destek olunması gerektiğini dile getirenler \%99,5 iken kısmen önemli olarak \%0,5'tir. Önemsiz olarak gören hiçbir katılımcı çıkmamıştır.

Tablo 17. Evlilikte mutlu yuva için çocuk sahibi olmak

\begin{tabular}{lll}
\hline & Sayı $(\mathrm{n})$ & Yüzde $(\%)$ \\
\hline Çok Önemli & 60 & 32,1 \\
Kısmen Önemli & 97 & 51,9 \\
Önemsiz & 30 & 16,0 \\
Total & 187 & 100,0 \\
\hline
\end{tabular}

Tablo 17 incelendiğinde araştırmaya katılan bireylerin evlilikte mutlu yuvanın olması için çocuk sahibi olmayı çok önemli ve kısmen önemli olarak nitelendirenler $\% 84$ iken önemsiz olarak görenler $\% 16$ dır.

Tablo 18. Evliliğe Yüklenen Anlam

\begin{tabular}{lllllllll}
\hline Evliliğin & anlamı & \multicolumn{2}{c}{ Çok Önemli } & \multicolumn{2}{c}{ Kismen Önemli } & \multicolumn{2}{c}{ Önemsiz } & \multicolumn{2}{l}{ Toplam } \\
düşünülünce & Sayı & $\mathbf{\%}$ & Sayı & $\mathbf{\%}$ & Sayı & \% & Sayı & \% \\
\hline Sorumluluk & 157 & 84,0 & 29 & 15,5 & 1 &, 5 & 187 & 100 \\
Hayatı paylaşmak & 178 & 95,2 & 9 & 4,8 & 0 & 0 & 187 & 100 \\
Monoton olmak & 20 & 10,7 & 80 & 42,8 & 87 & 46,5 & 187 & 100 \\
Özgürlüğün & 18 & 9,6 & 77 & 41,2 & 92 & 49,2 & 187 & 100 \\
kisitlanmasıdır & & & & & & & & \\
\hline
\end{tabular}

Tablo 18 incelendiğinde oransal olarak baktığımızda evliliğin hayatı paylaşma noktasında çok önemli olduğunu belirtenlerin oranı $\% 90,2^{\prime}$ dir. Ayrıca evliliğin sorumluluk olduğunu düşünen ve çok önemli olduğunu dile getirenlerin oranı ise $\% 84,0^{\prime}$ dır. Bu cevaplardan katılımcların evliliğe olumlu bir anlam yükledikleri görülmektedir.

Tablo 19. Evlilik sizi korkutuyor mu?

\begin{tabular}{lll}
\hline & Sayı $(\mathbf{n})$ & Yüzde (\%) \\
\hline Evet & 108 & 57,8 \\
Hayir & 79 & 42,2 \\
Total & 187 & 100,0 \\
\hline
\end{tabular}

Tablo 19 incelendiğinde araştırmaya katılan bireylerin \%57,8 (108)' i evlilikten korktuklarını ifade ederken \%42,2 (79)'si ise korkmadığını ifade etmiştir. 
Tablo 20. Evetse evlilik sizi neden korkutuyor?

\begin{tabular}{lll}
\hline & Sayı(n) & Yüzde (\%) \\
\hline Geçim Sıkıntısı Yaşamaktan & 16 & 8,6 \\
Sorumluluk Almaktan & 41 & 21,9 \\
Evlilik Sonrası Eşimin Değişmesinden & 37 & 19,8 \\
Evlilik Öncesi Yapabildiklerimi Sonrasında Yapamamaktan & 20 & 10,7 \\
Evlilikten Korkan Toplam Kişi & 114 & 61,0 \\
Hayır Diyenler & 73 & 39,0 \\
Total & 187 & 100,0 \\
\hline
\end{tabular}

Tablo 20 incelendiğinde araştırmaya katılan bireylerin \%21,9 (41)'u sorumluluk almaktan, \%19,8 (37) ise evlilik sonrası eşinin değişmesinden korktuğunu ifade etmiştir. Çalışmaya katılım sağlayanların en çok evliliğin sorumluluk gerektirdiği düşüncesiyle sorumluluk almaktan korktukları görülmüştür. Evlilik öncesi tanıdıkları eşlerinin evlendikten sonra tanıdıkları hallerinden farklı tavır ve davranış içine girmelerinin katılımcıları korkuttuğu görülmektedir.

Tablo 21. Aile kurumunun günümüzdeki durumu düşününce

\begin{tabular}{lll}
\hline & Sayı (n) & Yüzde (\%) \\
\hline Değeri Giderek Artıyor & 19 & 10,2 \\
Değeri Giderek Azalıyor & 138 & 73,8 \\
Fikrim yok & 30 & 16,0 \\
Total & 187 & 100,0 \\
\hline
\end{tabular}

Tablo 21 incelendiğinde araştırmaya katılan bireylerden \%73, 8 (138)'i aile kurumunun değerinin giderek azaldığını ifade etmiştir. Arttığını düşünenlerin oranı ise \%10,2 (19)'dir.

\section{Tartışma ve Sonuç}

Üniversite mezun sayısının artışı aynı zamanda yeni iş piyasasında çalışacak, iş arayışlarına girecek bireylerin de artışına sebep olmaktadır. Üniversite sonrası iş sahibi olmak mezun olunan alanda çalışmak herkesin talep edeceği bir durumdur. Mezun sayısının artışı aynı zamanda insanların iş kaygısını da arttırmaktadır.

Yapılan çalışmaya baktığımızda üniversite öğrencilerinin ileride evlenecekleri eşlerinin kariyer sahibi olmasının kısmen önemli olduğu görüşüne sahiplerdir. Katılım sağlayan kadınlardan kariyerin kısmen önemli olduğunu düşünenlerin oranı \%50,7 iken erkek katılımcılardan 
kısmen önemli olduğunu düşünenlerin oranı ise $\% 54,7$ dır. Katılımcıların bu noktada kariyere çok önem vermediği kısmen önemli olduğunu düşündükleri görülmektedir.

Katılımclların eğitim durumu hakkında görüşlerine baktığımızda kadın ve erkeğin eğitim durumunun eşit olması gerektiğini ifade etmişlerdir. Ayrıca çalışmaya katılan kadın katılımcılar eşlerinin üniversite mezunu olmasının kısmen önemli olduğunu vurgularken $(\% 45,5)$ erkekler ise önemli $(\% 50,9)$ olduğunu vurgulamıştır. Verilere baktığımızda çalışmaya katılan kadın ve erkeklerin yarısının hemen hemen üniversite mezuniyetine çok önem vermediği görülmektedir.

Kadın katılımcılar evlilik için erkeğin mutlaka iş sahibi olması gerektiği görüşündedirler. Çalışmaya katılan kadınların \%96,4'ü erkeğin iş sahibi olmasının çok önemli olduğu görüşündedirler. Erkek katılımcılar da kadın katılımcılarla aynı görüştedir. Kadınların iş sahibi olmasının çok önemli olduğunu belirten erkeklerin oranı \%81, 1'dir. Baş ve Cengiz (2018) tarafından yapılan bir araştırmada üniversite öğrencileri evlilik kararını vermeden önce eğitimi tamamlayıp iş sahibi olduktan sonra evliliğin düşünülebileceğini belirtmişlerdir (s.10). Özkiraz, Arslanel ve Şengül (2016)'ün yapmış olduğu çalışmada üniversite öğrencileri hayatta başarmak istedikleri en önemli şeyin ne olduğu sorusuna katılımcıların yarısından fazlası (\%56,6) okulu bitirip mesleğe başlamak olduğunu belirtmişlerdir (s.257).

Eş seçiminde üniversite mezunu olma durumu normal düzeyde önemsenirken iş sahibi olma durumunun çok önemsendiği görülmüştür. Sadece iş sahibi değil aynı zamanda eşlerin kariyer sahibi olması da istenmektedir. Bununla bağlantılı olarak katılımcılar eş seçiminde iş sahibi olunması ve üniversite mezunu olunması durumunu daha çok önemserken kariyer sahibi olmayı daha az önemsedikleri görülmüştür.

Kariyerin yanı sıra katılımcıların büyük çoğunluğu eşlerinin iyi ve güzel ahlaklı olmasını istemektedir. Üniversite öğrencilerinin bu yöndeki talebi eşlerinin hem kariyer sahibi olmaları aynı zamanda iyi huylu olmalarıdır. Çalışmaya katılım sağlayanların büyük çoğunluğu kariyer sahibi ve iyi huylu olmasının yanı sıra âşık olma durumunu da önemsemektedir. Ayrıca eşler arası kültürel durumlarında önemli olduğunu ifade etmişlerdir. Diğer önemli bir konu ise hayata bakıştır. Çalışmaya katılım sağlayanlar aynı zamanda hayata bakışı da önemsemektedir. Bu dikkat 
çeken bir konudur. Farklı yaş gruplarında bu durum belki de önemsenmezken daha genç grup olarak görülen üniversite öğrencileri hayata bakışı önemsemektedir.

Dikkat çeken bir veri ise katılımcıların hepsinin mutlu bir yuva için karşılıklı sevginin çok önemli olduğunu ifade etmesidir. Sevginin yanı sıra mutlu bir evliliğin karşılıklı anlayış, destekle olacağına katılanların sayısı da oldukça yüksektir. Evliliği sorumluluk, hayatı paylaşmak, mutlu ve huzurlu olmak şeklinde görenlerin sayısı yüksektir. Ayrıca özgürlüğün kısıtlanması olarak görenlerin sayısı ise görmeyenlere göre azdır. Baş ve Cengiz (2018)'in yapmış olduğu çalışmada üniversite öğrencileri evliliği "yuva kurmak", "yeni bir hayatı paylaşmak", "mutlu ve bir birliktelik" şeklinde tanımlanmaktadır (s.6). Keldal (2021) 'ın yaptığı nitel bir çalışmada gençlerin evlilikten beklentilerinin "hayatı paylaşmak", "düzenli bir yaşam", "huzurlu güvenli bir ortam" cevaplarını daha çok verdikleri görülmüştür (s.5). Gençlerin evlilikten beklentilerinin mutluluk, huzur ve hayatı paylaşmak olduğu görülmektedir.

Çalışmaya katılım sağlayanların büyük çoğunluğu evlilikten korkmaktadır. Çoğunlukla evlilikten korkma sebebi olarak sorumluluk almak ve evlilik sonrası eşin değişme ihtimalidir. Kadın katılımcıların \%61,9 u evlilikten korkmaktadır. Erkek katılımcıların kadınlara göre nispeten evlilikten daha az korktukları $(\% 47,2)$ görülmüştür. En çokta çalışmaya katılım sağlayan 2000 ve sonrasında doğanların evlilikten korktukları $(\% 62,9)$ görülmüştür. Yeni neslin evlilikten daha çok korktuğu ve korkmalarının sebebinin ise sorumluluk almak olduğu görülmüştür. Erkol, Şahin ve Avcı (2021)'nın yapmış olduğu çalışmada evlilikte üstlenilmesi gereken sorumlulukların gençlerin zihninde negatif bir şekilde yer aldığı görülmüştür (s.67-68)

Katılımcıların birçoğu kadın için ideal evlilik yaşının 24-26 (\%65,2) yaş arası olduğunu belirtmiştir. Aynı şekikde erkekler için de 24-26 (\%47,1) yaş aralığının ideal olduğu belirtilmiştir. Erkol, Şahin ve Avcı (2021)'nın yaptığ 1 çalışmada da evlilik için uygun yaş sorulduğunda en çok verilen cevabın 25-26 olduğu görülmüştür (s.64). Farklı çalışmalarda da benzer sonuçların çıktığı görülmüştür (Akbaş, Sürücü-Gökyıldız, Köroğlu-Onat ve Öztürk, 2019: 96, Özkiraz, Arslanel ve Şengül, 2016: 258). 
Çalışmaya katılanların kendi aile yapılarına göre evlilik birliğinin önemi hakkında farklı görüşe sahip oladukları görülmektedir. Ebeveynleri boşanmış olan katılımcılar $(\% 71,4)$ anne babası evli $(\% 41,8)$ olan katılımclara göre evliliği kısmen önemli olarak görmektedir. Yalçın, Kılıçoğlu-Arslan ve Acar (2017)'ın yapmış olduğu çalışmada ebeveyni evli, boşanmış ya da ayrı yaşayanların evliliğe yönelik tutumları açısından cinsiyete göre farklılaşma durumu incelendiğinde, boşanmamış ailelere sahip bireylerin evliliğe yönelik tutumlarının boşanmış ailelere sahip bireylere göre yüksek bulunmuştur (s.862). Anne babanın evli ya da boşanmış olması katılımcıların evlilik hakkındaki görüşlerini etkilediği görülmektedir.

Ekonomik sebepler, evlilik birliğini kurmak için yüksek maliyetin gerekmesi, işsizlik gençler için evliliğin ertelenmesinin en önemli sebepleri arasında yer almaktadır (Erkol, Şahin ve Avcı, 2021, s.67). Yapılan çalışmaya baktığımızda da ekonomik kaygının varlığı görülmektedir. Evi artık tek kişinin değil iki kişinin geçindirmesi gerektiği görüşü vardır. Erkeklerin de artık çalışan bir eş istedikleri çalışmanın verilerinden görülmektedir.

Gençler kariyer sahibi olmaktan ziyade iş sahibi olmak istemektedir. Üniversite mezuniyeti ile birlikte iş sahibi olma yaşı da ilerlemiştir. Bu sebeple de evlilik yaşı da uzamaktadır. Bu sebeple iş durumunun aile kurmayı da doğrudan etkilediği görülmektedir. Gençlerin yalnızca iş sahibi ya da kariyer sahibi biri değil aynı zamanda iyi huylu biri ile evlenmek istediği görülmüştür. Dolayısıyla kriterlerin artması evlilik yoluna girmeyi de zorlaştırmaktadır. Gençler kariyerli bir iş ya da üniversite mezunu olunmasından daha ziyade iş sahibi olunmasının altını önemle çizmişlerdir. Buda üniversite eğitimi gören gençlerin bu konuda kaygı duyduklarını göstermektedir. İş sahibi olamama ihtimali gençleri evlilik konusunda da çekimser bırakmaktadır. Aile ve evlilik hakkında geleneksel değerlerinin büyük bir kısmını korudukları ancak diğer taraftan beklentilerinin değiştiği de görülmüştür. 


\section{EXTENDED ABSTRACT \\ The Effect of Career Anxiety on Family Institution and Marriage Decision \\ Mukadder Özkan Bardakcı \\ Selçuk University}

Anxiety can occur in every person for different reasons. Career, on the other hand, is a process that continues with youth and university years, which are included in our lives with childhood. Many people dream of having a career job. It is a desirable situation that is imagined throughout the education process. While career covers the whole life of a person, anxiety can include certain periods. Especially in the life period, critical events, certain life periods, exams and diseases cause people to feel anxiety. Along with the state of anxiety, human life is also adversely affected. It harms people, especially psychologically.Undoubtedly, it is after university graduation that anxiety will be felt the most at this time, from childhood to youth, where the dream of a career with a career is dreamed. As the end approaches, students worry about whether they will have a career or career. For this reason, since career anxiety is thought to affect life after university more, interviews were conducted with university students. This is not the only reason for selecting university students in this study. It is thought that especially university students have different perspectives on life. The new generation's view of marriage and family may be different.

Career anxiety isn't the only issue after college graduation. With graduation, the time for marriage and starting a family is approaching. The family is the most basic institution that forms the basis of the society and is undoubtedly established by the union of marriage. Every person needs family. It is family members who support people in many ways. Family is where people first socialize. It is the first school where every person gets education. Therefore, it is an important institution. Family is formed by marriage. Therefore, marriage union is necessary for people to be a family. For this reason, both marriage and family are two important institutions that cannot be separated from each other. Over time, people's perspectives 
on family and marriage change. Marriage rates are declining, especially compared to the past. People prefer a more individual, freer life. Both economic reasons and perspective can be an obstacle to starting a family. At the same time, the types of families in which individuals live (broken family, extended family, nuclear family, single-parent family) can change the view of family and marriage togetherness.

People and generations change over time. This change can be reflected in family life as well as marriage. Both economic and professional concerns can make the younger generation think about marriage. At the same time, it is thought that increasing divorces and changes in living standards are also effective. The desire to have a more luxurious life or a more career profession can be seen as an obstacle to marriage. Not only these reasons, but also many reasons such as individual desire to live, being free, career career, economic freedom, avoiding responsibility prevent individuals from getting married and starting a family. It is observed that the age of marriage has increased compared to the past. Late marriage raises the question of whether the marriage rates will decrease gradually in the following years. In the light of all these reasons, the views of young people, especially university students, on issues such as career, marriage and family have been a matter of curiosity.

In this study, it is investigated the impact of career anxiety on family institution and marriage decision making. İncluding university students, 187 students took part in study. Sample group was picked from the students in Faculty of Management (651 students), Faculty of Tourism (169 students), Vocational School (1790 students) and School of Applied Sciences (321 students) in Beyşehir district. İn this study the method of simple random sampling was used. Trying to communicate with students via media made it difficult to obtain data while it could be obtained easily. A questionnaire with 90 questions including demographic questions was applied in the study to obtain data for the purpose of determining point of views of study group to marriage and family institution with career anxiety. In questionnaire quantitative research and questions were used as methods, the data was analyzed SPSS 20 programme. In the study, there is frequency distribution. The students taking part in the study regard that their partners have a career or a job. On the other hand, they also care mutual love and being happy. It is seen that the students participating in 
the study are afraid of marriage. They expressed the reason for this as taking responsibility and the thought that the spouses they met before marriage will change with marriage.

\section{Kaynakça / References}

Akbaş, M., Sürücü- Göyıldız, Ş., Köroğlu- Onat, C. ve Öztürk, M. (2019). Üniversite öğrencilerinin evlilik tutumlarını etkileyen faktörler. Cukurova Medical Journal, 44(1), 93-100.

Akkaya, K. (2018). Toplumsal değişimin aile kurumuna etkisi bağlamında çokeşli evlilikler: Erzurum \Hınıs Örneği. Yüksek Lisans Tezi. Üsküdar Üniversitesi Sağlık Bilimleri Enstitüsü, İstanbul.

Atasoy, G. (1994). Aile huzuru. İstanbul: Yeni Asya Yayınları.

Balaman, A. R. (1984). Kırsal kesimde: Aile kurma, çözme, aile içi etkileşim ve ilişkiler. Türkiye'de aile değişimi (Toplum bilimsel incelemeler). Ankara: Türk Sosyal Bilimler Derneği Yayını.

Baş, E. ve Cengiz, E. (2018). Üniversite öğrencilerinin evlilik ve aileyi anlamlandırma biçimleri. Imgelem, 2(2), 1-23.

Çağ, P. ve Yıldırım, İ.(2013). Evlilik doyumunu yordayan ilişkisel ve kişisel değişkenler. Türk Psikolojik Danışma ve Rehberlik Dergisi, 4(39), 13-23.

Çakmak, Ö. ve Hevedanll, M. (2005). Eğitim ve fen edebiyat fakülteleri biyoloji bölümü öğrencilerinin kaygı düzeylerinin çeşitli değişkenler açısından incelenmesi. Elektronik Sosyal Bilimler Dergisi, 4(14), 115-127.

Can, İ. (2013). Tarih, toplum ve kültür bağlamında aile ve kadın. Sistematik Aile Sosyolojisi. (Ed. M. Aydın). Konya: Çizgi Kitabevi.

Erkol, M., Şahin, M. ve Avcı, Ş. (2021). Toplumsal değişimin bir göstergesi olarak gençlerin evliliğe yönelik tutumları. Universal Journal of History and Culture, 3(1), 57-78.

Eroğlu,Ş. (2017). Evliliklerini 20 yaş altı yapmış kadınlar ile evliliklerini 20 yaş üzerinde yapmış olan kadınların yaşam doyumları, evlilik uyumları ile cinsel doyumları açısından karşılaştırılması. Yüksek Lisans Tezi. Beykent Üniversitesi, Sosyal Bilimler Enstitüsü, İstanbul.

Fouad, N. A., Guillen, A., Harris-Hodge, E., Henry, C. and Terry, S. (2006). Need, awareness, and use of career services for college students, Journal of Career Assessment, 14, 407-420. 
Göncü Akbaş, M., ve Okutan, E. (2019). 15-24 yaş arası öğrencilerin kariyer kaygılarını incelemeye yönelik literatür araştırması. Siyaset, Ekomomi ve Yönetim Araştırmaları Dergisi, 7(1), 33-41.

Keldal, G. (2021). Evliliğe bakış açısı ve evlilikten beklentiler. Çukurova Üniversitesi Sosyal Bilimler Enstitüsü Dergisi, 30(1), 1-10.

Nacak, İ. ve Karaarslan, F. (2013). Ailenin yapısı: Bir sistem olarak aile. Sistematik Aile Sosyolojisi. (Ed. M. Aydın). Konya: Çizgi Kitabevi.

Ozankaya, Ö. (1999). Toplumbilim. (9. baskı). İstanbul: Cem Yayınevi

Özkiraz, A., Arslanel, N. M. ve Şengül, T. (2016). Gaziosmanpaşa Üniversitesi öğrencilerinin aile kurumuna bakışı. Atatürk Üniversitesi İktisadi ve İdari Bilimler Dergisi, 30(2), 243-268.

Sarı, Ö. (2013). Aile kurumu ve ailenin tanımı. Sistematik Aile Sosyolojisi. (Ed. M. Aydın). Konya: Çizgi Kitabevi.

Tandoğan, H. (1965). Aile hukuku. Ankara: Yargı Yayınları.

Yalçın, H., Kılıçoğlu-Arslan, E. ve Avar, A. (2017). Gençlerin evlilik ve toplumsal cinsiyet rollerine ilişkin tutumları. Uluslararası Sosyal Araştırmalar Dergisi, 10(52), 858-865.

Yörükoğlu, A. (2000). Çocuk ruh sağhlğı çocuk yetiştirme sanatı ve kişilik gelişimi. (24. Basım). İstanbul:Özgür Yayınları.

Yörükoğlu, A. (2004). Gençlik çă̆ı ruh sağllğı ve ruhsal sorunlar. (12. Basım). İstanbul: Özgür Yayınları.

\section{Kaynakça Bilgisi / Citation Information}

Özkan Bardakcı, M. (2021). Kariyer kaygısının aile kurumuna ve evlilik kararına etkisi. OPUS-Uluslararası Toplum Araştırmaları Dergisi, 18(42), 5610-5630. DOI: 10.26466/opus. 920663. 